\title{
ATTRIBUTES OF CREATIVE SECTOR ORGANIZATIONS AS DETERMINANTS OF RISK MANAGEMENT ${ }^{1}$
}

\author{
ATRYBUTY ORGANIZACJI SEKTORA KREATYWNEGO \\ JAKO DETERMINANTY ZARZĄDZANIA RYZYKIEM
}

\author{
JACEK WOŹNIAK \\ jacekj.wozniak@wat.edu.pl \\ MILITARY UNIVERSITY OF TECHNOLOGY \\ FACULTY OF CYBERNETICS \\ WIOLETTA WEREDA \\ weredawioletta@tlen.pl \\ MILITARY UNIVERSITY OF TECHNOLOGY \\ FACULTY OF CYBERNETICS
}

\begin{abstract}
Nowadays, the role and importance of the creative sector are increasing in many national economies. In order to ensure a strong and positive impact of the sector on the economic development of different countries, first this sector has to be strengthened internally. This involves caring for normal development of the creative sector by ensuring that its entities are in good "shape". The article focuses on the microeconomic plane coupled with the meso-economic one. The creative sector focuses on broadly-understood culture (it links e.g. the higher culture and applied goods, e.g. design), which affects the way of its development in different dimensions, e.g. the market, relational, technical ones, etc. Strengthening the creative sector requires implementation and improvement of specific risk management processes. The article presents an analysis of risk management conditions in creative sector organizations. The main area of considerations is identification of the attributes of creative sector organizations as determinants of risk management.
\end{abstract}

Keywords: management, organization, risk, creative sector, risk factors.

Streszczenie: Współcześnie wzrasta rola i znaczenie tzw. sektora kreatywnego w wielu gospodarkach narodowych. Dążąc do tego, aby wpływ tego sektora na rozwój gospodarczy różnych krajów był silny i dodatni, wpierw należy umacniać ten sektor od wewnątrz. Chodzi tu o dbanie o prawidłowy rozwój sektora kreatywnego poprzez zapewnianie odpowiedniej „kondycji” tworzącym go podmiotom. W artykule następuje koncentracja na płaszczyźnie mikroekonomicznej sprzężonej z perspektywą mezoekonomiczną. Sektor kreatywny skupia się na szeroko rozumianej kulturze (łączy m.in. dobra kultury wyższej i dobra stricte użytkowe, np. design), co rzutuje na sposób jego rozwoju w różnych wymiarach, np. rynkowym, relacyjnym, technicznym itp. Umacnianie sektora kreatywnego wymaga wdrożenia i doskonalenia specyficznych procesów zarządzania ryzykiem. W artykule analizowane są uwarunkowania zarządzania ryzykiem w organizacjach z sektora kreatywnego. Szczególny nacisk położony jest na identyfikację atrybutów organizacji z sektora kreatywnego jako determinantu zarządzania ryzykiem.

Słowa kluczowe: zarządzanie, organizacja, ryzyko, sektor kreatywny, czynniki ryzyka.

The article is financed from the public science funds as a research project No. RMN 812/2016 (Faculty of Cybernetics, Military University of Technology in Warsaw). 
The current issue of "Modern Management Systems" features two articles regarding the broadly-understood problem of shaping development of organizations, presented in the RMN 812/2016 research study conducted at the Faculty of Cybernetics, Military University of Technology in Warsaw. The studies apply to risk management in creative sector organizations and focus on how risk should be interpreted and identified and how to develop risk management for that to be a holistic tool for shaping development of organizations. Both articles are theoretical and each complements the other. While the first study indicates that risk management in creative sector organizations should be holistic; the second one presents the holistic approach to risk management in a more detailed way, indicating how the effect of the "holistic approach" can be achieved in practice.

\section{Introduction}

Contemporary societies are increasingly willing to participate in the processes of creation and dissemination of broadly understood cultural goods, both locally and globally. At the same time, culture is increasingly embedded in people's lives - it enables development (both professional and personal) by having an impact on one's beliefs and presenting previously unexplored aspects of world functioning. Culture establishes a basis for self-fulfilment by addressing material and spiritual needs. This characteristic reorientation towards consumption of higher level material goods (such as clothes and furniture design) and non-material experiences (theatrical plays, film festivals etc.) of societies in various parts of the world (mainly in developed, post-industrial countries) favours the development of the so-called creative sector, which is intended to create and disseminate cultural objects with the use of, among others, innovative processes. In a number of countries we can see a rapid growth pattern of the creative sector thanks to demand for culture sensu largo (aesthetic experience and innovative durables). Organizations operating within the sector have specific, common attributes, which enable the sector to be viewed as a relatively consistent in itself set of entities. It is key to development of the whole sector-specific risk management system. Risk management in creative sector organizations should both be initiated or shaped in the same way as in creative sector entities, as it may be the source of additional threats.

The theoretical objective of the article is to identify the underlying attributes of organizations making up the creative sector which may have an effect on risk management processes. Whereas, the utilitarian objective is to specify the basic principles of development of risk management processes in creative sector organizations. The scope of the study concerns the analysis of the fundamental mechanisms and conditions of operation of creative sector organizations as visualised by, among other things, classification of economic activities that may be important to risk management processes. The research problem here is as follows: which attributes of creative sector 
organizations determine the specificity of risk management processes and in what way? The main research methodology is critical literature review supplemented with methods of deduction and synthesis.

The article is composed of the following four parts: (1) definitions of the creative sector, (2) classification of business activities within the creative sector, (3) identification of specific determinants of operation of creative sector organizations as a benchmark of risk management, and (4) determination of guiding principles for risk management processes.

\section{Various approaches to defining the creative sector}

The term "creative sector" first emerged in Australia, with the 1994 report entitled Creative Nation. The document was introduced to a broader audience in the U.K. in 1997, with the establishment of Creative Industries Task Force by the Department of Culture, Media and Sport. Definitions of the creative sector have evolved ever since to take on various shapes in different countries (Creative Economy Report, 2008, p. 11).

The creative sector may be considered from either a broad or a narrow perspective. From the narrow perspective, the creative sector consists of "creative enterprises, particularly market-oriented, dealing with the creation, production, distribution and/or dissemination of creative goods and services through the media" (Mackiewicz, Michorowska, Śliwka, 2009, p. 7). According to R. Kasprzak (2013, p. 3) the creative sector is "the zone of social services including the area of business activity oriented to the creation and commercialisation of the products of culture, involving various types of business activity organizational structures". Whereas, according to the definition presented by the British Department for Culture, Media and Sport (DCMS), the creative sector represents "those industries which have their origin in individual creativity, skill and talent and which have a potential for wealth and job creation through the generation and exploitation of intellectual property" (Creative Industries Mapping Document: Background, 2001, p. 05). In other words, the creative sector "generates value through the establishment of intellectual property rights and exploitation of cultural objects for the creation of non-culture products (design, graphic design, advertising)" (Górniak et al., 2013, p. 13).

The primary focus of definitions (from the narrow perspective) is on commercial activities (commercialisations of goods produced within the sector), which eliminates non-profit making bodies from the creative sector set. Nevertheless, the approach of R. Kasprzak seems most broad-ranging, for instance by allowing different structures of business activities.

In turn, the definition included in Creative Industries in Berlin. Development and Potential is equivalent to the broad perspective, as in addition to commercial activities sensu stricto it accounts for the following: (1) public-funded cultural services; and (2) non-profit non-government organizations conducting cultural operations 
(Creative Industries in Berlin. Development and Potential, 2008, p. 5). The creative sector is viewed from a broad perspective also by some Polish researchers in the field. P. Lewandowski, J. Mućk oraz Ł. Skrok (2010, p. 7) indicate that the creative sector comprises the field of culture and the creation of intermediate goods and services (such as advertising). The creative sector is composed of elements of the so-called high culture (operations of theatres, philharmonic orchestras, museums, art galleries etc.) and the so-called mass culture (for instance film and music industry, popular literature or computer graphics) (Górniak et al., 2013, p. 13). A broad and at the same time most precise approach is presented in the definition found in Creative Economy Report (2008, p. 13) indicating that "the creative industries:

1) are the cycles of creation, production and distribution of goods and services that use creativity and intellectual capital as primary inputs,

2) constitute a set of knowledge-based activities, focused on but not limited to arts, potentially generating revenues from trade and intellectual property rights,

3) comprise tangible products and intangible intellectual or artistic services with creative content, economic value and market objectives,

4) are at the cross-road among the artisan, services and industrial sectors and

5) constitute a new dynamic sector in world trade".

The above definition is assumed to be primary and binding herein, mainly because of its exposition of the dynamics and complexity of the sector, which may have a correlation with risk management processes.

Here, it is also useful to relate to the definition by J. Howkins (original source: Howkins, 2007), indicating that the creative sector is "a holistic concept which changed approach to arts, media, and design by combining them with digitalisation, creativity and intellectual capital" (Dziurski, 2016, p. 129). These intrinsic generation factors are key means of conveying values in the creative sector that carry specific risk. Furthermore, we must remember that said factors are dependent not only on internal conditions of organizations within the creative sector but also on other, external entities, which must be accounted for in the processes of risk management. The underlying types of activities in the creative sector are: culture-based activities (associated exclusively with the production of the so-called creative products, and in many cases non-commercial, as it is anchored in the public and non-government sectors) and functional activities (typical commercial activities, such as design companies) (based on: Grochowski et al., 2012, pp. 15-16). Organizations within the creative sector operate in a sector-specific environment which encompasses, most of all, all other knowledge- and innovation-oriented entities. The above group includes, in particular: research and development bodies, foundations, training companies, private companies focused on specific technologies, e.g. manufacturing technologies The creative sector organizations are surrounded by various types of institutions, for instance EU bodies, Polish offices, and state technological infrastructure, etc.

Here, we should mention that the Creative Industries Economic Estimates (2015, p. 5) published by DCMS distinguishes between the creative economy and 
the creative sector (or industries). It defines the creative economy as the one which includes the contribution of those who are in creative occupations outside the creative sector as well as all those employed therein. The creative sector (or industries) is, in turn, presented as a subset of the creative economy which encompasses only those working in the creative sector itself (and who may either be in creative occupations or in other roles e.g. finance) (Creative Industries Economic Estimates, 2015, p. 5).

\section{Creative sector structure}

The preceding part encompassed various approaches to defining the creative sector. These different perspectives are a result of, in particular, its inner structure. As indicated by M. Ratalewska (2014, p. 384), generally subject literature lacks a uniform classification of activities undertaken as part of the creative sector. One of the major criteria determining the variability of inner classification of the creative sector is the ratio of commercial activities to non-commercial activities. Another issue within the field of creative sector structuring is the criterion of organization size and the legal type of organization. Micro-enterprises and individuals, the socalled freelancers, often not accounted for in statistics, have important shares in the creative sector (Ratalewska, 2014, p. 384). Another characteristic is that, in principle, the creative sector, by drawing on the unique characteristics of the commercial, public and social (non-government) sectors, lays down its own rules of operation, which in turn affects approaches to risk management processes. For instance, organizations within the media industry and included in the creative sector may be commercial entities and bodies conducting non-profit activities. The situation is similar with regards to publishing houses, theatres, etc. In addition, such entities may be publicly funded. The complexity of internal structure of the creative industries is, to a certain extent, a consequence of the sector being a real "lap" over creative, public and social sectors (Fig. 1).

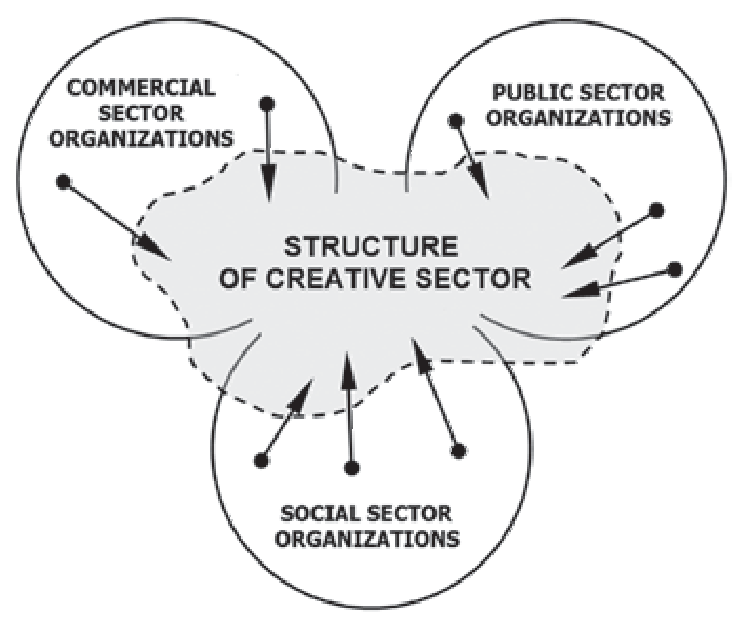


By making a reference to the classification set forth in Creative Industries Mapping Document: Background (2001, p. 05), we may assume that the creative sector is composed of the following activity types: performing arts, music industry, art and antiques market, crafts, publishing, television and radio, film and video, computer games and video, designer fashion, advertising, architecture and urban design, software and computer services, and design. The above activities are divided into three main sub-sets (Kasprzak, 2013, p. 1):

1) arts and crafts sub-set: performing arts, art and antiques market, crafts,

2) creative production sub-set: publishing, music industry, radio and television, film and video, computer games and video, designer fashion,

3) creative services sub-set: advertising, architecture and urban design, so$\mathrm{ftware}$ and computer services, design.

Each of the three groups has its unique characteristics. Overall, it may be concluded that (based on: The Economy of Culture in Europe, 2006, p. 355, [in:] Bochińska, Palczewska, 2008, p. 7):

- the arts and crafts sub-set creates the so-called non-industrial cultural objects / goods that may be "consumed on the spot",

- the creative production sub-set creates cultural objects / goods destined mainly for mass audience (where copyrights are key to their dissemination),

- the creative services sub-set is a source of services rooted in the broadly understood culture; activities in the sector are performed rather on an individual scale; copyrights and patents are key to services dissemination.

There is another interesting creative sector business activity classification suggested by NESTA (2006, pp. 54-55), listing the following sub-sets:

1) creative service providers,

2) creative content producers,

3) creative experience providers,

4) original creative content producers.

Both classifications are consistent and, in principle, are founded on similar assumptions as they list three essentially related groups of activities: (1) creative services; (2) creative production (i.e. creative content providers); and (3) arts-and crafts-oriented activities (i.e. original creative content producers and creative experience providers).

\section{Characteristic features of creative sector organizations from risk management perspective}

As indicated herein above, the creative sector is internally diversified - it is composed of entities engaged in activities ranging from production, through services, to design. The entities by commercial (business), public or non-government sector organizations.

However, we may identify some essential attributes based on which we may treat the creative sector as a set of bodies of a similar general activity profile. 
The initial part of the study indicates, most of all, that the common element of the creative sector entities is their focus on development and dissemination of broadly-understood culture, for instance, in the aspect of a stricte functional activity or cultural experience. In other words, as noted by the authors of the report entitled Bilans kompetencji: Wybrane segmenty branży kreatywnej (Górniak et al., 2013, p. 13) - "The creative industries are made up of enterprises with products feature a great degree of originality of content and a significant input of talent, skill and creation of their authors". As we can see, the leading attributes of the creative sector are: originality, innovation in the process of goods and services creation, and lateral thinking in problem solving. Therefore, employee (craftsmen, artists, designers, etc.) skills / competence (both soft skills, in relations with customers and art audience, and hard skills, i.e. professional competence), are of particular importance. More generally, creative sector employees should contribute broadly-understood creativity (Rogoda, 2012, p. 207). From this perspective, the remark of S. Olko (2014, p. 43) "Competencies in creative industries are much harder to analyse than, for instance, technological competencies, guided by well-recognised norms and standards". It thus transpires that the essence of employee competence is determined by the profile of business activity of a given creative sector organization. In addition, analysis and evaluation of employee competence require a reference to the processes of risk management due to uncertainty and no structuring or standardisation of competencies. While we are on the subject of risk management, we need to note that specific competencies of creative sector employees result in no big threat from mechanization and automation of processes. Therefore, creative sector organizations are characterised by resilience to the reduction of employment. Instead, we are witnessing a trend that is quite the opposite, a continued demand for specialists (Marcus, 2005, p. 8 and following). Here, it is worth pointing out that, by principle, organizations in the creative sector differ little in skills (e.g. of designers, architects, actors, craftsmen, music producers, etc.), but much in remunerations (Caves, 2000, [in:] Lewandowski, Mućk, Skrok, 2010, p. 10), which might be a source of risk factors within an organization, for instance interpersonal conflicts leading to a loss of intellectual capital (dismissals).

Organizations within the creative sector have a large impact on social change as they refer to elements embedded in culture. Thus, not only do they have a creative impact, in the form of products, but they also create intangible assets (based on: Hausner, 2013, pp. 92-93, 100, 488, [in:] Sobocińska, 2016, p. 17). B. Rogoda (2012, p. 207) thinks similarly by saying that the effects of activities of creative sector organizations "are carriers of symbolic information, which in addition to utilitarian benefits give recipients some additional value", for example, in the form of cultural experience, by inspiring to undertake one's own activity, through the creation of new patterns of behaviour, or when stimulating creativity. Changing the society also entails the need to implement risk management processes. 
In their desire to maximize effects of their actions, creative sector organizations often establish network structures in the form clusters (see Jankowska, 2012, p. 110 and following), which allows them, amongst other things, to have a strong and positive synergy effect. Within the risk management context, relations of coopetition, seen as something rather positive in the creative sector (see e.g. [in:] Jankowska, 2012, pp. 113-118), and as a threat in the "traditional" sectors, especially in micro- and small enterprises, are growing in importance. However, cooperation with competitors within the creative sector involves specific focus on intellectual property protection, which largely determines organizations' competitive potential and is ascribed either to a particular individual or a group of authors (based on: Rogoda, 2012, p. 207). We may even assume that one of the principles of risk management in creative sector organizations is indeed the protection of intellectual property.

Owing to the specificity of offered goods and services (i.e. the experimental nature and subjectivity of experience), activities of creative sector organizations feature a relatively high level of uncertainty as regards customer / recipient demand. Moreover, art and higher values are often ends in themselves for authors. This is mainly typical of activities focused on culture, although, it may be accounted for also in functional activities, such as those of designers, architects, fashion and furniture designers, etc. The creative process, especially in complex undertakings, requires coordination of the timing of specific knowledge resources and creativity, which can be challenging due to the fact that the effects of work are the result of creative inspiration rather than something done on request. Thus, projects may be delayed (which generates costs) or the quality of effects is reduced. Quite importantly, the combination of production factors is unique - it differs even between creative sector organizations of a similar business profile. This distinctive group of resources, which generates the value added for an organization and the customer / recipient (based on: Caves, 2000, [in:] Lewandowski, Mućk, Skrok, 2010, p. 10).

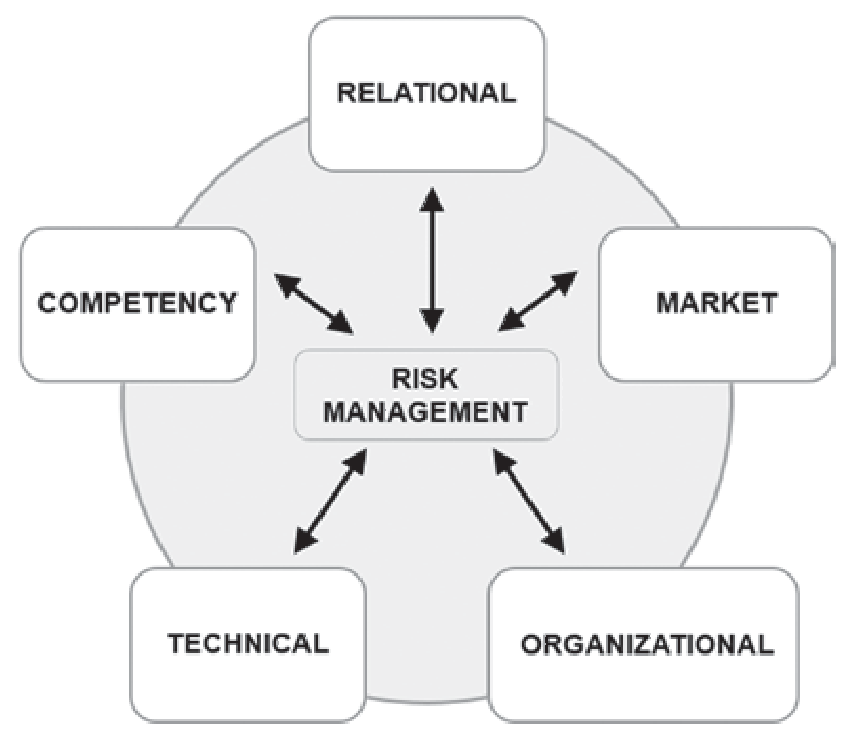


Herein above, we have presented only the basic attributes of creative sector organizations, largely typical of the majority of industries within the sector (taking into consideration its internal diversity). These attributes, within the risk management conditions context, may be seen in the framework of five basic dimensions (Fig. 2): Relational, Organizational, Technical, Competency, and Market (Tab. 1).

Tab. 1. Dimensions of activities of creative sector organizations as sources of threats

\begin{tabular}{|c|c|c|c|}
\hline No. & $\begin{array}{c}\text { Basic } \\
\text { dimensions } \\
\text { of activities }\end{array}$ & Typical elements included & Selected threats ${ }^{*}$ \\
\hline 1. & Relational & $\begin{array}{l}\text { - relations with co-operators, } \\
\text { - relations with competitors, } \\
\text { - relations with public administra- } \\
\text { tion and non-profit organizations, } \\
\text { - relations with key customers, } \\
\text { - relations with public opinion }\end{array}$ & $\begin{array}{l}\text { - no external funding, } \\
\text { - no consideration for public } \\
\text { opinion needs in creative pro- } \\
\text { cesses, } \\
\text { - infringing intellectual property } \\
\text { rights }\end{array}$ \\
\hline 2. & Organizational & $\begin{array}{l}\text { - building up of resources processes, } \\
\text { - division of responsibility be- } \\
\text { tween employees processes, } \\
\text { - classification of key employee } \\
\text { competencies processes, } \\
\text { preparing production processes, } \\
\text { resource timing }\end{array}$ & $\begin{array}{l}\text { - limited employee / creator access } \\
\text { to expertise created in global } \\
\text { economy (around the world), } \\
\text { - employees with creativity and } \\
\text { knowledge do not communicate } \\
\text { with each other in creative pro- } \\
\text { cesses }\end{array}$ \\
\hline 3. & Technical & $\begin{array}{l}\text { - use of information and commu- } \\
\text { nication technologies (ICTs) in } \\
\text { creative processes and customer } \\
\text { relations, } \\
\text { - use of ICTs in the processes } \\
\text { of distribution / dissemination } \\
\text { of cultural products }\end{array}$ & $\begin{array}{l}\text { - ICTs are not a brand develop- } \\
\text { ment tool or a key to knowledge } \\
\text { resources, } \\
\text { - lack of integration of knowledge } \\
\text { resources management processes } \\
\text { in organizations }\end{array}$ \\
\hline 4. & Competency & $\begin{array}{l}\text { - employee knowledge, expe- } \\
\text { rience, and professional skills, } \\
\text { - social skills }\end{array}$ & $\begin{array}{l}\text { - authors / designers are not } \\
\text { able to establish relations with } \\
\text { customers / clients }\end{array}$ \\
\hline 5. & Market & $\begin{array}{l}\text { - conducting activities to obtain } \\
\text { financial benefits, } \\
\text { - increasing competitive potential } \\
\text { and market share, } \\
\text { - conducting cost calculations } \\
\text { and operational efficiency analy- } \\
\text { ses, } \\
\text { - conducting market analyses and } \\
\text { suiting the offer to the needs of } \\
\text { customers / clients (satisfying de- } \\
\text { mand). }\end{array}$ & $\begin{array}{l}\text { - increase of importance of process- } \\
\text { es within the so-called new con- } \\
\text { sumption category (expressed by } \\
\text { mega-trends, such as servitisation, } \\
\text { dematerialization, home-centrism, } \\
\text { virtualization, individualisation, } \\
\text { and prosumption, makes it dif- } \\
\text { ficult for organizations to meet } \\
\text { customer needs (Bywalec, 2010, } \\
\text { pp. 194-226; Sowa, 2010, pp. 179- } \\
\text {-189, [in:] Sobocińska 2016, p. 21). }\end{array}$ \\
\hline
\end{tabular}

${ }^{*}$ In creative sector organizations, these dimensions may be a source of chances, too

Source: own work 
Dimensions of organizational activities are interrelated, they are complementary, to some extent they overlap, even in substance, and they affect risk management (e.g. by a diversified compilation of threats) in creative sector organizations. We can observe an inverse reaction, i.e. the processes of risk management determine the change of the character of elements included in particular dimensions (Fig. 2).

\section{Basic principles of risk management processes development}

The process of risk management processes in creative sector organizations is complex. In order to properly develop and implement such processes, one should pay attention in particular to the following principles:

1) risk management should be customer-centred, i.e. focused on the recipient of tangible and intangible values, as this may support processes of demand forecasting, and result in a more precise income evaluation; customer, his needs, abilities and expectations must be properly defined, mainly in the field of the created value added; what is also of importance are a skilled segmentation of the market and an inclusion of the customer / recipient in the creative process (prosumption), which can facilitate risk management processes (e.g. by threat transfer and a faster identification of risk factors) and, at the same time, increase the level of satisfaction and loyalty of customers;

2) risk management should be multidimensional, accounting not only for the area of finance but also for technical, relational, environmental, competency, and other related issues; paying attention to finance-related threats is insufficient, it is more than just financial capacity that determines the broadly-understood economic safety of creative sector organizations - the key players here are, amongst others, social trust, loyalty and sympathy of customers, and image / market-related attractiveness;

3) risk management in creative sector organizations should always join two surfaces: the global and the local one; it is a highly globalised sector (architecture, industrial design, fashion design etc.), which should not, however, respond to local-scale needs (i.e. in a given country, region or even a city); both global opportunities and risks may affect the scope and quality of the way various needs of local customers are satisfied by certain organizations;

4) in addition to management, all employees in creative sector organizations should be included in risk management processes, i.e. artists, publishers, designers, architects etc.; every and each of these positions may be a source of both threats and developmental opportunities for organizations and should have an effect on decision-making processes regarding risk management system development; specialists in operations departments in the creative sector play a major role from the perspective of risk management 
since they create the whole value added for a customer / recipient (they are the source of intellectual capital development); said specialists either have direct relations with customers / recipients, or they need to develop a concept of a good or a service in such way that is meets the needs of the environment; specialists in operations departments may be then considered the first and principal stage during which threats can occur in production processes and developmental opportunities can be created;

5) risk management in creative sector organizations should comprise two sides to risk - positive and negative; in other words, creative sector organizations should be actively involved both in risk protection and in the creation and use of development opportunities (which means they should have a certain level of risk-taking); it is result of the fact that creative sector organizations aspire for trend development and value innovativeness.

All in all, it should be noted that this is only a selection of basic principles regarding risk management.

\section{Summary}

During the design and implementation of risk management processes in creative sector organizations one should bear in mind that both risk interpretation and risk management should stem from the characteristic features of the sector and individual organizations at the same time (i.e. organizations which are within a network of relations). Therefore, risk management processes should centre on the customer / recipient of cultural experience, characterized by a relatively high level of culture and expecting content which would satisfy his needs (supporting his self-fulfilment). In a majority of cases it is not a "mass" audience that largely follows the price criterion. One of the key areas of risk management should be the development of employee intellectual capital. It is interesting that this capital (for instance, in the form of knowledge and skills) should be a reflection of both global and local trends. Additionally, managing key employee teams in the creative sector (e.g. designers, copywriters, fashion designers, IT specialists) is differs significantly from managing typically production-oriented teams, for instance, in terms of working time and task scheduling, enforcement of work effects, or the broadly-understood care for "intellectual comfort" of work. Activities undertaken within the creative sector are often capital-intensive and time-consuming, but difficult in terms of profitability estimation, and it mainly, though not exclusively, concerns operations based on culture sensu stricto. What is more, creative processes require rare resources, without which one may guarantee neither high quality (and as a consequence, value added for customer / recipient) nor competitive advantage (and the creative sector is characterized by strong competition). Another area to be included in risk management processes is the financing of creative activities, which in many cases is more than pure commerce. We may assume that the risk 
management areas indicated herein above are key for creative sector organizations (but not the only ones). In summary, risk management, treated as an illustration of specifics of creative sector organizations, must comply with principles of the holistic approach.

\section{BIBLIOGRAPHY}

[1] Bywalec Cz., 2010, Konsumpcja a rozwój gospodarczy i społeczny, C.H. Beck, Warszawa.

[2] Caves R.E., 2000, Creative Industries: Contracts between Art and Commerce, Harvard University Press.

[3] Creative Economy Report, 2008, United Nations Conference on Trade and Development, United Nations Development Programme.

[4] Dziurski P., 2016, Modele zarzadzania organizacjami w sektorze wzornictwa przemysłowego w Polsce. Opinia ekspertów, [in:] M. Menkes (ed.), Wkład nauk ekonomicznych w budowę kapitału społecznego, Oficyna Wydawnicza Szkoły Głównej Handlowej w Warszawie, Warszawa.

[5] Hausner J., 2013, Kultura i polityka rozwoju oraz Zakończenie, [in:] J. Hausner, A. Karwińska, J. Purchla (eds.), Kultura a rozwój, Narodowe Centrum Kultury, Warszawa.

[6] Howkins J., 2007, The Creative Economy. How People Make Money from Ideas, Penguin Books, London.

[7] JanKowsKa B., 2012, Koopetycja jako atrybut klastra - przypadek jednego z klastrów kreatywnych, „Uniwersytet Szczeciński. Zeszyty Naukowe No. 719: Ekonomiczne Problemy Usług No. 94", titled: Klastry - Wiedza, Innowacyjność, Rozwój.

[8] Lewandowski P., Mućk J., Skrok Ł., 2010, Znaczenie gospodarcze sektora kultury. Wstęp do analizy problemu, Raport końcowy, Instytut Badań Strukturalnych, Warszawa.

[9] Olкo S., 2014, Badanie kompetencji w sieciach i klastrach w przemysłach kreatywnych, „Zeszyty Naukowe Politechniki Śląskiej”, series: „Organizacja i Zarządzanie”, vol. 76.

[10] Ratalewska M., 2014, Przedsiębiorczość w sektorach kreatywnych, „Prace Naukowe Uniwersytetu Ekonomicznego we Wrocławiu", No. 347.

[11] Rogoda B., 2012, Hybrydowe modele biznesu w sektorach kreatywnych i ich funkcja ekonomiczna, „Uniwersytet Szczeciński. Zeszyty Naukowe no. 714: Ekonomiczne Problemy Usług No. 90", titled: Kształtowanie procesów innowacyjnych w nowoczesnych organizacjach, SOOIPP Annual 2012.

[12] SовосіŃsKa M., 2016, Produkty systemowe w sektorze kreatywnym - znaczenie $i$ determinanty rozwoju, „Studia Ekonomiczne. Zeszyty Naukowe Uniwersytetu Ekonomicznego w Katowicach", No. 262.

[13] Sowa I., 2010, Nowe trendy w zachowaniach konsumentów, [in:] E. Kieżel (ed.), Konsument i jego zachowania na rynku europejskim, PWE, Warszawa.

[14] The Economy of Culture in Europe, 2006, Report of KEA European Affairs for the European Commission, October. 


\section{Internet Sources:}

[1] Bochińska B., Palczewska I., 2008, Diagnoza stanu wzornictwa, November, http://www.kongreskultury.pl/library/File/RaportWzornictwo/wzornictwo_raport_w. pelna(1).pdf [28.07.2016].

[2] Creative Industries Economic Estimates, 2015, Statistical Release, Department for Culture, Media and Sport, London, January, https://www.gov.uk/government/uploads/ system/uploads/attachment_data/file/394668/Creative_Industries_Economic_ Estimates_-_January_2015.pdf [20.07.2016].

[3] Creative Industries in Berlin. Development and Potential, 2008, Senatsverwaltung für Wirtschaft, Technologie und Frauen (Senate Department for Economics, Technology and Women's Issues), Berlin, December, http://www.ndpculture.org/media/ W1siZiIsIjIwMTQvMDcvMzAvMXczeHhtcTB5NV9SZXBvcnRfQ3JlYXRpdmVfS W5kdXN0cmllc19CZXJsaW5fMjAwOC5wZGYiXV0?sha=fe243b0f4ab5fe28 [17.07.2016].

[4] Creative Industries Mapping Document: Background, 2001, Department for Culture, Media and Sport, London, https://www.gov.uk/government/uploads/system/uploads/ attachment_data/file/183544/2001part1-foreword2001.pdf [05.07.2016].

[5] GóRniAK J. ET AL., 2013, Bilans kompetencji. Wybrane segmenty branży kreatywnej, Kraków, October, www.krakow.pl/zalacznik/71487 [21.08.2016].

[6] Grochowski M. ET AL., 2012, Sektor kreatywny w województwach pomorskim i kujawsko-pomorskim, Gdańsk, https://kreatywni.arp.gda.pl/plik,54,raport-skb-2012pdf.pdf [25.06.2016].

[7] KASPRZAK R., 2013, Typologia przemysłów kreatywnych zastosowana na portalu Obserwatorium Przemysłów Kreatywnych, Warszawa, http://ekonomiawkulturze.pl/ res/opk/003-typologia-przemyslow-kreatywnych.pdf [31.08.2016].

[8] Mackiewicz M., Michorowska B., Śliwka A. (cooperation: M. Grochowski), 2009, Analiza potrzeb i rozwoju przemysłów kreatywnych, Warszawa, November, http://nck.pl/ media/study/analiza_potrzeb_i_rozwoju_przemysw_kreatywnych.pdf [1.08.2016].

[9] Marcus C., 2005, Future of Creative Industries. Implications for Research Policy, Foresight Working Documents Series, European Communities, April, http://meakultura.pl/cdn/docs/1326303611.pdf [25.03.2016].

[10] NESTA, 2006, Creating growth. How the UK can develop world class creative business, National Endowment for Science, Technology and the Arts, London, April, https://www.nesta.org.uk/sites/default/files/creating_growth.pdf [17.05.2016]. 